\title{
Research on Foreign Exchange Risk Management of Cross-border Supply Chain Enterprises
}

\author{
Lu Yao \\ Fujian Provincial Humanities and Social Sciences Base — Finance and Audit Information Research Center \\ Xiamen Huaxia University \\ Xiamen, China 361024
}

\begin{abstract}
Against the background of economic globalization, cross-border supply chain is applied in the development of enterprises, which has broadened the market scope to some extent. However, it will be affected by foreign exchange risk. This paper first describes the performance of foreign exchange risk in cross-border supply chain. Secondly, it analyzes the current risk status. Finally, it combines the author's work experience and knowledge to explore the management of foreign exchange risk in cross-border supply chain from various angles, including supply chain finance, risk aversion tools, corporate marketing strategies, trading strategies, settlement currency, etc. Based on this, it is hoped that this paper can provide valuable reference for relevant personnel, promote enterprises to comply with the development trend of economic globalization, timely prepare for risk prevention and management, and achieve effective control of foreign exchange risk.
\end{abstract}

Keywords-cross-border supply chain; foreign exchange risk; risk management

\section{INTRODUCTION}

The implementation of the "New Exchange Reform" policy has improved the formation mechanism of the exchange rate intermediate price. In order to create a stable development space for the cross-border supply chain, the RMB has adjusted the bilateral exchange rate against the US dollar. The role of this approach has promoted the marketization of the RMB in the exchange rate of the US dollar, while also reflecting the supply and demand relationship in the foreign exchange market. The implementation of this method facilitates the implementation of foreign exchange risk management in cross-border supply chain and reduces the impact of risk issues on business results.

\section{PERFORMANCE OF FOREIGN EXCHANGE RISK IN CROSS-BORDER SUPPLY CHAIN}

\section{A. Economic Risks}

Cross-border supply chain is subject to economic risks in the development of international markets. This kind of risk is one of the manifestations of foreign exchange risk. Specifically, economic risks are affected by changes in exchange rates during the trade of foreign currency capital items, which adversely affect the earnings of operating enterprises. After economic risks occur, all cooperative units in the cross-border supply chain, whether it is trade activities or market expansion, will be restricted. Under the premise of exchange rate fluctuation, the products marketed by the supply chain will be adjusted in terms of cost, pricing and quantity, which will reduce the expected economic benefits [1].

For example, Company A establishes a cooperative relationship with an importer in the UK to form a crossborder supply chain and at the same time, sign a trade contract. According to the contract, Company A sells 240 refrigerators to UK importers. Among them, the currency of price is in US dollars, and the currency of settlement is in pounds sterling. In the process of cooperation between the two parties, Company A begins to produce refrigerators according to the terms of the contract. However, the pound depreciated during the period. Previously, Company A purchased a new production line in order to guarantee the quality and production efficiency of the refrigerator. The funds needed for the production line are mainly bank loans. Therefore, companies can't violate the relevant treaties and stop the production of refrigerators. Affected by the above factors, Company A experienced difficulties in capital turnover during the period of operation and development, which made the company unable to obtain economic benefits in the cross-border supply chain, and even suffered losses.

\section{B. Trading Risks}

In the trade of cross-border supply chain, trading risk is also one of the main manifestations of foreign exchange risk. In the case of changes in the exchange rate, both parties to the transaction will experience serious economic losses. Most cross-border trades are denominated in foreign currency. Therefore, in the case of a significant change in the exchange rate, the cash flow of the trading company itself will increase and decrease due to changes in the exchange rate. Affected by this factor, if the cross-border supply chain lasts longer, the foreign exchange risk will have a more serious impact, and it won't be able to guarantee the crossborder supply chain enterprises to obtain corresponding benefits in the trade.

For example, A Trading Company has established a partnership with the US market and sells them $\$ 250,000$ 
worth of goods. In the process of signing the contract, it is determined according to the exchange rate between the US dollar and the RMB at that time, that is, 1 US dollar is equal to 6.4 yuan. However, the transaction contract sets the payment period as 30 days. Suppose that after the contract expires, the exchange rate between the US dollar and the RMB at the time of receipt of the contract is US\$1 equals 6.3 yuan. Then the sales value of the goods can only get 1.57 million yuan. Therefore, the trading company will charge 25,000 yuan less than when the contract is signed. The emergence of this phenomenon will bring serious economic losses to trading companies. For all companies in a crossborder supply chain, the emergence of this phenomenon will limit the long-term development of many aspects. Therefore, it must be given relevant attention and managed in an appropriate manner.

\section{Conversion Risks}

In addition to the above-mentioned economic risks and trading risks, cross-border supply chain will also be affected by the conversion risk in business development. This risk is also one of the main manifestations of foreign exchange risk. Specifically, the conversion risks are mainly due to the risk impact caused by the conversion between the bookkeeping currencies. In the case of changes in foreign exchange, the value of the project funds will change accordingly. At this time, it is easy to appear the phenomenon of enterprise paper losses. The emergence of such risks will also bring serious economic losses to cross-border supply chain enterprises and increase the difficulty of obtaining economic benefits from international markets.

For example, Company A plans to purchase a device worth US\$1 million for better operation and development. The exchange rate between the US dollar and the RMB during the purchase period is 1 US dollar equals to 6.6 RMB. Therefore, the value of the equipment is equivalent to 6.6 million RMB. However, when the enterprise clears the accounting accounts at the end of the year, the exchange rate of the US dollar changes to 1 US dollar equals 6.4 RMB. Therefore, the calculation of the accounts will result in a converting difference of 200,000 yuan. That is to say, enterprises will face an exchange loss of 200,000 yuan caused by the changes of exchange in the process of purchasing the equipment.

\section{THE STATUS QUO OF FOREIGN EXCHANGE RISK IN CROSS-BORDER SUPPLY CHAIN}

\section{A. Imbalance of Import and Export Business}

In recent years, as China's material living standards have been significantly improved, domestic consumers have begun to turn their target markets abroad and even become keen to buy global luxury goods. Such as: American brand bags, Swiss brand watches, Dutch brand milk powder, and French brand cosmetics. The emergence of this phenomenon has brought new development opportunities to cross-border supply chain. According to the official data of the Ministry of Commerce, the scale of cross-border e-commerce transactions has increased, which has driven the development of the global economy to some extent. At the same time, however, there has also been a phenomenon of imbalance in import and export business. Specifically, in the current cross-border trade, export trade reaches 4.49 trillion yuan, while the scale of imports was only 0.91 trillion yuan. The emergence of this phenomenon has increased the degree of imbalance between the import and export of international trade [2].

At present, China's cross-border supply chain mainly presents two modes: B2C and B2B. The essence of the B2B model is actually the business-to-business model. Complete the release of information and advertising through ecommerce. The related processes and transaction payments will be completed offline. In contrast, the essence of the B2C model is the business-to-consumer business model. Also based on the Internet, the retail business is launched online. Consumers can make an order payment through the network to obtain the corresponding product. Among them, "Fig. 1" is the cross-border supply chain model of the B2C model. Specifically, domestic consumers will pay the purchase price to a third-party e-commerce after completing the order. At this time, the settlement is in RMB. After the goods are delivered, the third-party platform will pay the goods to the overseas supplier. At this time, the method of foreign exchange settlement will be adopted. During this period, if the RMB depreciates, cross-border e-commerce needs to bear the economic losses caused by foreign exchange risks. 


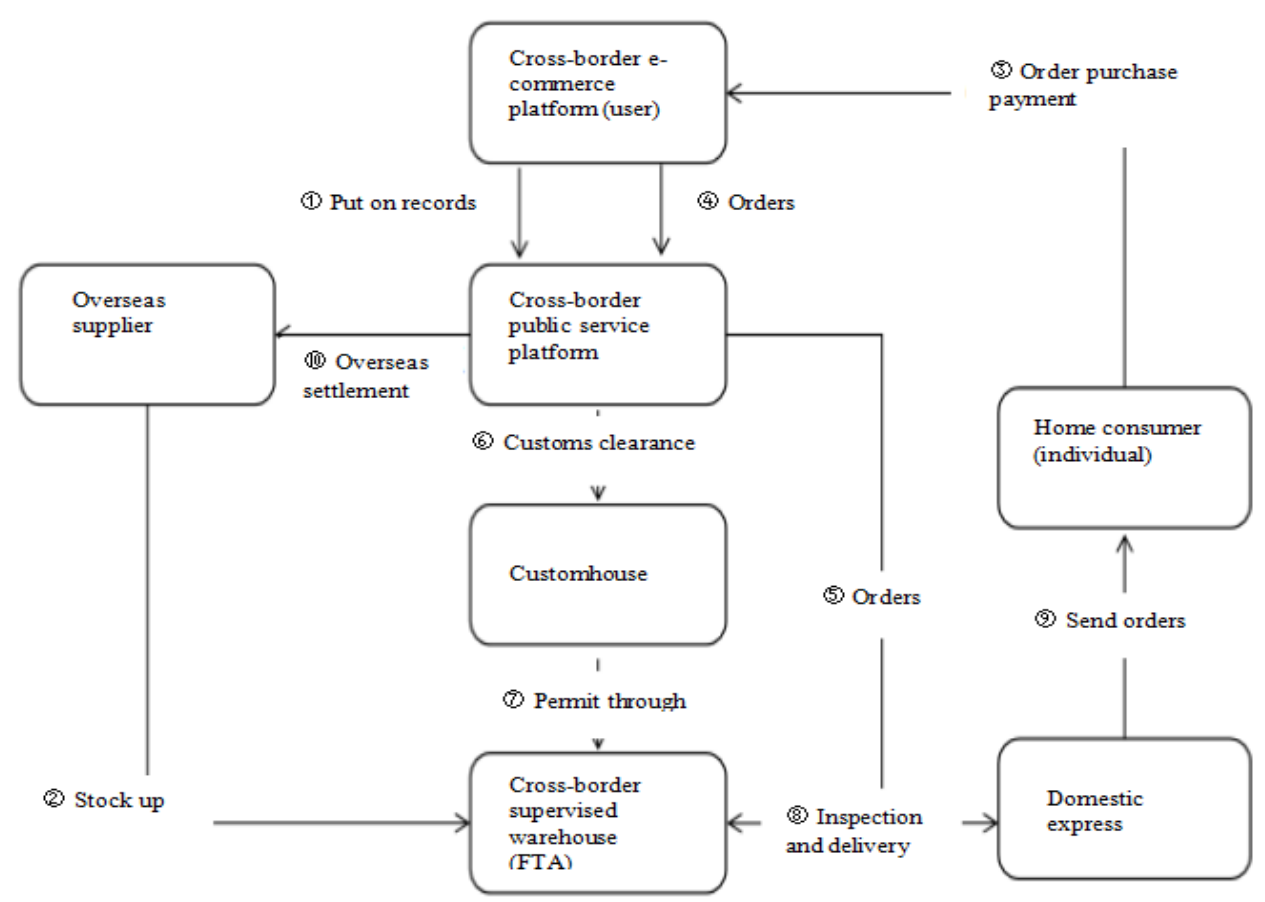

Fig. 1. B2C Model Import Business Process.

\section{B. The Improper Use of Tools}

On the premise of the "Internet Plus" and wide use of big data technology, China's cross-border supply chain enterprises have developed rapidly. Among them, crossborder e-commerce has been the main form of cross-border supply chain enterprises. For example, Suning Overseas Shopping, Jingdong Global Shopping, Tmall Global, Wan Guo You Pin, Amazon, Ymatou, etc., provide consumers with an international shopping platform. It is this phenomenon that has caused cross-border supply chain companies to face problems such as exchange rate fluctuations and price competition. To a certain extent, it has increased the challenges of business management and development. Under normal circumstances, cross-border supply chain will complete operations and sales through logistics, warehousing, and pricing, so they will ignore exchange rate risks. Therefore, during the process of pricing, the platform products are generally priced according to the current exchange rate. And after the offer is determined, it's can't be changed casually.

If the offer of the product is relatively high, it will lead to the loss of consumers. However, if the offer of the product is relatively low, then the enterprises need to bear the foreign exchange risk. Combined with the fluctuation of the RMB exchange rate, cross-border supply chain enterprises actually need to combine their own development intentions to rationally apply different risk estimation tools. Then, the enterprises should combine its own strategy to determine risk management measures to achieve effective control of risks and reduce economic losses. But from the current situation, the use of risk aversion tools by cross-border supply chain enterprises is inappropriate, and it is impossible to properly analyze changes in international exchange rates. After the exchange rate fluctuations occur, it is basically necessary for the company to accept the risks in its entirety. This phenomenon can not only obtain the corresponding economic benefits, but also limit the long-term development of enterprises [3].

\section{THE MANAGEMENT OF FoREIGN EXCHANGE RISK IN CROSS-BORDER SUPPLY CHAIN}

\section{A. Playing the Role of Supply Chain Finance}

In order to achieve the purpose of cross-border supply chain foreign exchange risk management, it is necessary to give full play to the role of supply chain finance and fully consider the risk factors of RMB depreciation and appreciation, so as to formulate a more scientific risk management plan. Specifically, cross-border supply chain companies can achieve management objectives through the following measures:

1) Risk management in the case of RMB depreciation:

Assumption: In the process of cross-border trade, Jingdong Global Shopping platform needs to pay a deposit of 100,000 Euros per year to the French Lancome brand. The manufacturer will then send a cosmetic product worth 300,000 Euros to the China Free Trade Area and settle the settlement according to the order. At the end of the year, the manufacturer will return the entire deposit of 100,000 Euros to the Jingdong platform. Combined with the trend of exchange rate between the Euro and the RMB, Jingdong Global Shopping platform adopts supply chain finance to manage foreign exchange risk and achieve effective control 
over economic losses. After reasonable predictions, it is found that the RMB shows a trend of continued depreciation. If the interest rate of the RMB loan is lower than the interest rate of the Euro loan, a one-year RMB loan can be made at the beginning of the year.

Subsequently, all RMB are exchanged into Euros for payment of the deposit. At the end of the year, the Jingdong platform will recover the deposit of 100,000 Euros and convert it into RMB for repayment of loans. And based on this, within one year, Jingdong platform can reduce the risk of exchange rate changes through supply chain finance and realize the rational use of relevant policies. In the abovementioned way, even if there is an error in the prediction of the exchange rate, it won't bring serious economic losses to the Jingdong platform. In this case, the changes in exchange rates are beneficial to the deposit paid by the platform. It should be noted that if the interest rate of the current RMB loan is higher than the interest rate of the Euro loan, the interest rate difference should be taken into account as the main factor.

\section{2) Risk management in the case of RMB appreciation:}

Assumption: In the process of cross-border trade, Jingdong Global Shopping platform needs to pay a deposit of 200,000 AUD per year to the Australian baby milk powder brand. The manufacturer will then send 500,000 AUD worth of milk powder products to the China Free Trade Area and settle the settlement according to the order. At the end of the year, the manufacturer will return the full amount of the 200,000 AUD deposit to the Jingdong platform. In combination with the changing trend of exchange rates between the AUD and the RMB, Jingdong Global Shopping platform uses supply chain finance to manage foreign exchange risk and achieve effective control over economic losses. After reasonable prediction, it is found that the RMB has shown a trend of continuous appreciation. In the case that the RMB loan interest rate is higher than the AUD loan rate, the platform can apply for a loan of 200,000 AUD at the beginning of the year for the same period of one year, and use this fee to pay the deposit [4].

At the end of the year, the manufacturer will return the deposit to the platform. Therefore, the platform can complete the repayment of principal and interest according to a lower interest rate. In this case, the impact of exchange rate fluctuations on deposit is bad, and the application of loans through the AUD can avoid the impact of risk. However, in the case of RMB appreciation, it is very beneficial to the order of the platform, that is, the price paid by the consumer is higher than the overseas settlement price, which is beneficial to the platform to obtain more economic benefits. Conversely, if the RMB loan interest rate is lower than the AUD loan interest rate, if the loan is applied for RMB loans at the beginning of the year, it will have a negative impact on the deposit. However, this risk can be offset by low interest costs and exchange rate gains on platform transactions.

\section{B. Rational Use of Risk Aversion Tools}

Cross-border supply chain enterprises should rationally apply risk aversion tools in the process of managing foreign exchange risk. Specifically, during cross-border trade, enterprises need to strengthen their risk management methods through derivative financial instruments. It can effectively prevent foreign exchange risks while providing basic guarantees for the economic benefits of enterprises. Among them, derivative financial instruments mainly include:

\section{1) Forward foreign exchange transactions:}

During the cross-border supply chain transaction, when the two parties sign the contract, they can pre-specify the exchange rate of the trading currency, so that the enterprise can determine the cash flow paid and the cash flow received in advance. In this way, the economic loss of exchange rate changes can be avoided and the forward-looking of risk management can be further strengthened. As a result, enterprises are able to accurately measure fixed risk costs and keep risks within acceptable limits.

\section{2) Foreign exchange option transactions:}

In the process of cross-border trade, enterprises can combine the relevant provisions of foreign exchange option transactions, and after completing the payment of the option fee, they can choose the corresponding exchange rate opportunity to carry out economic and trade activities. In fact, the essence and function of foreign exchange options is to preserve the value of foreign exchange, so that enterprises can make reasonable planning and choices about exchange rate changes. At the same time of risk management, enterprises can obtain more economic benefits and even achieve economic value-added effects.

\section{3) Foreign exchange futures transactions:}

Such trading methods can use foreign exchange futures to improve the stability of future monetary funds and thereby avoiding the impact of exchange rate changes on the benefits of cross-border supply chain.

\section{Continuously Optimizing Enterprise Marketing Strategies}

In the process of economic and trade, cross-border supply chain should use marketing methods reasonably to achieve effective management and prevention of foreign exchange risks. Among them, the main marketing strategies mainly include the following points:

1) Making reasonable choices in the trading market:

Enterprises need to analyze the foreign exchange market in light of their own actualities and clarify the foreign exchange risk situation in different market areas. If there is a high foreign exchange risk in the target market, the trade volume should be well controlled, and a stable market should be selected as much as possible for economic trade. At the same time, enterprises need to consider the economic environment, financial situation, political environment and other factors of the trading market, so as to make more scientific choices [5].

\section{2) Making reasonable choices of settlement time:}

In the process of cross-border trade, enterprises need to adjust the income time of cash flow to achieve effective evasion of foreign exchange risk. In order to achieve this 
goal, cross-border enterprises need to accurately predict the changes of RMB exchange rate and determine the settlement time on the basis of mastering specific laws. In this way, the adverse effects of foreign exchange risk can be avoided.

3) Enterprises need to make reasonable choices of the settlement currency:

Specifically, cross-border supply chain needs to adopt soft coin collocation to carry out cross-border trading activities, so as to effectively prevent foreign exchange risk. At the same time, this method can also ensure the reasonable sharing of foreign exchange risk between the two parties, and achieve the purpose of risk transfer and risk control.

\section{Giving Full Play to the Role of Trade Strategies}

In the process of promoting cross-border transactions, supply chain enterprises need to make reasonable adjustments to trade strategies and use them as entry points for foreign exchange risk management to reduce the impact of risk factors on corporate transactions. Firstly, enterprises need to adjust the timing of foreign exchange payments. The possibility of exchange rate fluctuations is closely related to the time of accounts payable and accounts receivable. Therefore, enterprises need to predict the trend of exchange rate changes, to achieve a reasonable choice of payment time, so as to avoid foreign exchange risk nodes, and thus maintain the economic benefits of enterprises. Secondly, trading enterprises can use the method of raising the price to maintain the value to realize the management of foreign exchange risk. Specifically, under the premise of considering commodity price, market and transaction intention, enterprises analyze and manage foreign exchange risk by means of raising or lowering the price to maintain the value. If the export enterprises adopt the way of raising the price of soft currency, it can make full use of the established valuepreserving clause in the contract to realize the transfer of foreign exchange risk. If the export enterprises adopt the method of coin pricing, it can effectively eliminate the foreign exchange risk through the commodity price. Finally, enterprises can shorten the time for export proceeds in foreign exchange. In other words, supply chain enterprises can deliver on time according to the terms of the contract in cross-border transactions, and achieve rapid recovery of foreign exchange, avoiding long-term delay and foreign exchange risk [6].

\section{E. Making Reasonable Choices of Transaction Settlement Currency}

In order to effectively control foreign exchange risk, cross-border supply chain should accurately grasp the international financial market; actively do a good job in foreign exchange budget and other related work to provide valuable reference for the reasonable choice of transaction settlement currency. In fact, in the process of foreign exchange settlement, there are many ways of pricing and settlement, which can meet the relevant needs of different supply chain enterprises. In the process of export trade, enterprises should choose the currency whose exchange rate shows an upward trend as much as possible, and use it as the main currency for pricing settlement. At the same time, enterprises should try their best to settle accounts in RMB. In this way, the risk of foreign exchange trading can be effectively avoided. In the import trade, enterprises should choose the currency that may have a falling exchange rate as the settlement currency. Based on this, it effectively improves the rationality of settlement currency selection and helps cross-border supply chain enterprises to realize foreign exchange risk management and prevention to the greatest extent.

\section{CONCLUSION}

In summary, the foreign exchange risk of cross-border supply chain is manifested at many different levels. For this reason, the current foreign exchange risk has not been effectively controlled, which has adversely affected the development of cross-border supply chain. In order to obtain more economic benefits globally, it is necessary to formulate a more targeted risk management plan based on the actual situation of foreign exchange and give full play to the important role of relevant policies and tools. In the long term, it is convenient for cross-border enterprises to achieve effective control over foreign exchange risk, minimize losses, and ultimately create a good market development environment and enhance the overall strength of enterprises.

\section{REFERENCES}

[1] Lang Deqing, Zhang Qian. Research on Trade Credit Management Based on the Perspective of Macro-prudential Management of Crossborder Funds [J]. Qinghai Finance, 2019(05): 23-28.

[2] Liu Jingxian. Research on the Opening of Foreign Exchange Market Under the Framework of Cross-border Capital Flow Risk Management [J]. Hainan Finance, 2018(08): 72-76.

[3] Wang Hua, Wang Bin.Study on the Development of Foreign Exchange Derivatives Market in China's Economically Developed Areas - Taking Anhui Province as an Example [J]. Journal of Chengdu Normal University, 2017, 33(11): 110-117.

[4] Li Xuewu. Identification and Monitoring of Cross-border Capital Flow Risk in China Under the Opening of Foreign Exchange Market [J]. Financial Development Review, 2017(10): 86-96.

[5] Zhao Feng, Ye Zi, Li Mengyu. Research on Foreign Exchange Risk Hedging Effect of Chinese Cross-border Investment Enterprises Based on the Perspective of Debt Tax Shield [J]. Journal of Beijing Technology and Business University (Social Science Edition), 2017, 32(01): $94-105$.

[6] Zhao Feng, Xiang Tiange, Ye Zi. Can Foreign Exchange Risk Hedging Reduce the Cost of Equity Financing of Enterprises? Based on the Perspective of Cross-border Investment Enterprise Classification Research [J]. Finance and Accounting Monthly, 2016(20): 100-106. 